\title{
Strategi Promosi Villa Alahan Panjang Resort Selama Pandemi Covid-19
}

\section{Ilham Ade Saputra 1*}

${ }^{1}$ Universitas Negeri Padang, Sumatra Barat, Indonesia

\section{ART ICLE INFO}

\section{Article history:}

Received August 10, 2021

Revised August 12, 2021

Accepted September 30, 2021

Available online October 25, 2021

Kata Kunci:

Strategi, Promosi, Villa

Keywords:

Strategy, Promotion, Villa

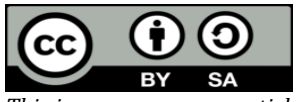

This is an open access article under the $\mathrm{CC}$ BY-SA license.

Copyright (C) 2021 by Author. Published by Universitas Pendidikan Ganesha.

\begin{abstract}
A B S T R A K
Pengelolaan promos Villa mengalami beberapa permasalahan salah satunya dikarenkan pada saat ini tengah berada dalam situasi pandemi COVID 19 yang menyebabkan terjadinya pemberlakuan Pembatasan Sosial Skala Besar (PSBB) sehingga seluruh kegiatan dibatasi. Tujuan penelitian ini yaitu menganalisis strategi promosi Villa Alahan Panjang Resort untuk dapat menarik minat pengunjung datang berkunjung dan menginap di Villa Alahan Panjang Resort. Metode penelitan menggunakan metode penelitian deskriptif. Data yang diperoleh akan dianalisis dan diinterprestasikan sesuai dengan tujuan dan pernyataan penelitian. Teknik yang digunakan dalam menentukan sampel yaitu teknik purposive. Untuk mendapatkan data penelitian dilakukan dengan cara melakukan wawancara, observasi, dan dokumentasi. Pertanyaan wawancara dilakukan menggunakan analisis SWOT (Strength, weakness, opportunity, dan treath). Hasil penelitian yaitu promosi yang dilakukan oleh Dinas Pariwisata selaku pengelola Villa Alahan Panjang Resort belum begitu baik karena minimnya promosi yang terkait dengan Villa Alahan Panjang Resort. Belum ditemukannya promosi berupa periklanan di area Villa Alahan Panjang Resort dan promosi penjualan berupa pemberian coupons, discount, dan cashback belum pernah dilakukan sama sekali. Berdasarkan hasil penelitian disarankan untuk meningkatkan kegiatan promosi Villa Alahan Panjang Resort berupa periklanan dengan menggunakan iklan cetak seperti pemasangan spanduk di kawasan destinasi wisata. Selain itu, dapat mengadakan promosi lain berupa promosi penjualan dengan memberlakukan pemeberian coupons, discount, dan cashback kepada pengunjung dengan syarat dan ketentuan yang berlaku.
\end{abstract}

A B S T R A C T

The management of the Villa promotion experienced several problems, one of which was due to the current situation of the COVID-19 pandemic, which caused the implementation of Large-Scale Social Restrictions (PSBB) so that all activities were limited. The purpose of this study is to analyze the promotion strategy of Villa Alahan Panjang Resort to attract visitors to come to visit and stay at Villa Alahan Panjang Resort. The research method uses descriptive research methods. The data obtained will be analyzed and interpreted by the objectives and research statements. The technique used in determining the sample is the purposive technique. To obtain research data is done by conducting interviews, observations, and documentation. Interview questions were conducted using SWOT (Strength, Weaknesses, Opportunities, and Threats) analysis. The research results are that the promotion carried out by the Tourism Office as the manager of Villa Alahan Panjang Resort has not been so good because of the lack of promotion related to Villa Alahan Panjang Resort. There has been no promotion in advertising in the Villa Alahan Panjang Resort area, and sales promotions in the form of giving coupons, discounts, and cashback have never been done. Based on the study results, it is recommended to increase the promotional activities of Villa Alahan Panjang Resort in the form of advertising by using print advertisements such as placing banners in tourist destination areas. In addition, they are holding other promotions in the form of sales promotions by providing coupons, discounts, and cashback to visitors with applicable terms and conditions.

\section{PENDAHULUAN}

Pariwisata adalah suatu perjalanan yang dilakukan oleh individu atau kelompok untuk sementara waktu, terjadi perpindahan dari suatu tempat ke tempat yang lain, dengan maksud untuk menikmati perjalanan dengan tujuan rekreasi bukan untuk mencari penghasilan di tempat yang dikunjungi dan memenuhi kebutuhan individu ataupun kelompok yang beranekaragam (Andrinata et al., 2016; Atiko et al., 2016; Nugroho et al., 2019; Paramita \& Putra, 2020). Salah satu faktor yang mempengaruhi minat wisatawan terhadap destinasi wisata adalah ketersedian akomdasi penginapan berupa hotel atau resort (Avello Martínez \& López Fernández, 2015; Hao et al., 2020; Sun et al., 2020). Hotel adalah suatu perusahaan yang dikelolah pemiliknya dengan menyediakan pelayanan makanan, minuman, fasilitas kamar untuk tidur kepada pengunjung (Fan et al., 2021; Perles-Ribes et al., 2016; Wikrama et al., 2017). 
Salah satu akomodasi yang ada di Kabupaten Solok adalah Villa Alahan Panjang Resort yang memiliki luas 30 hektar dan terdapat 36 kamar, 1 convention hall danbeberapa fasilitas pendukung lainnya. Villa Alahan Panjang Resort berada di Nagari Alahan Panjang, Kecamatan Lembah Gumanti, Kabupaten Solok, Provinsi Sumatera Barat.

Berdasarkan pra-penelitian yang peneliti lakukan langsung kepada pengelolahan Villa Alahan Panjang Resort tentang promosi Villa Alahan panjang Resort mengalami beberapa permasalahan salah satunya dikarenkan pada saat ini tengah berada dalam situasi pandemi COVID 19 yang menyebabkan terjadinya pemberlakuan Pembatasan Sosial Skala Besar (PSBB) sehingga seluruh kegiatan dibatasi. Masalah kedua adalah belum adanya promosi yang dilakukan oleh pengelola Villa Alahan Panjang Resort dengan memanfaatkan media sosial. Masalah ketiga adalah belum adanya promosi berupa spanduk yang dipasang di kawasan Villa Alahan Panjang Resort dan destinasi wisata lain yang ada di Kabupaten Solok. Permasalahan selanjutnya yaitu pada website Dinas Pariwisata dan Kebudayaan Kabupaten Solok belum ditemukan promosi tentang Villa Alahan Panjang Resort.

Pemahaman tentang promosi yaitu promosi merupakan sarana berkomunikasi dimana perusahaan berusaha menginformasikan, membujuk, mengingatkan konsumen secara langsung maupun tidak langsung tentang produk yang akan dijual (Atiko et al., 2016; Handoko, 2017; Indiyati et al., 2020). Selain itu promosi berujuan untuk merubah tingkah laku konsumen sebagai dampak informasi yang telah diterima melalui media promosi (Desmira et al., 2021; Hanaysha, 2017; Indiyati et al., 2020; Pratiwi et al., 2017). Agar tercapainya tujuan dari promosi dari promosi maka perusahaan perlu adanya strategi promosi dalam melakukan kegiatan promosi itu sendiri (Kotler \& Amstrong, 2012; Peñate-Valentín et al., 2021). Selanjutnya strategi promosi merupakan sebagai perencanaan, penerapan dan pengendalian komunikasi dari sebuah organisasi kepada pelanggan sasarannya dalam hal ini perencanaan digunakan untuk mengetahui dan mengidentifikasi kekautan dan kelemahan yang bertanggung jawab dalam aktifitas promosi yang dilakukan (Ali et al., 2013; Fransiska et al., 2012; Malaquias et al., 2019).

Dalam memasarkan suatu produk wajib menggabungkan promosi untuk mengkomunikasikan informasi tentang produk dan mempengaruhi konsumen untuk membeli suatu produk yang dipasarkan (Freixanet, 2016; Ramanathan \& Muyldermans, 2010). Terdapat empat jenis promosi utama seperti iklan, promosi penjualan, penjualan personal dan publisitas (Lang et al., 2022; Lim \& Chihyung, 2022). Iklan merupakan sebuah sarana dalam menyampaikan informasi mengenai produk kepada konsumen melalui media seperti majalah, radio, film, spanduk atau media lainnya (Cowan, 2020; English et al., 2016). Tujuan dari kegiatan promosi yaitu mengadakan sebuah komunikasi secara efektif dan meningkatkan penjualan. Terdapat dua faktor yang perlu diperhatikan dalam menerapkan strategi pengembangan yaitu dengan memperhatikan faktor internal dan eksternal, dimana faktor internal adalah kekuatan dan kelemahan yang dimiliki objek wisata, sementara faktor eksternal berupa peluang dan ancaman (Kotler, Philip \& Keller, 2016). Maka dari itu penting adanya strategi strenghts, weaknesses, opportunity, dan threaths (SWOT). Penelitian sebelumnya juga menyatakan bahwa pentingnya sebuah analisis dalam memasarkan sebuah produk (Kurniasanti et al., 2015; Rosidi et al., 2017). Berdasarkan pemaparan masalah diatas berkaitan dengan strategi promosi maka penelitian ini penting dilakukan guna meningkatkan kunjungan dan hunian Villa Alahan Panjang Resort. Tujuan penelitian ini yaitu menganalisis strategi promosi Villa Alahan Panjang Resort untuk dapat menarik minat pengunjung datang berkunjung dan menginap di Villa Alahan Panjang Resort.

\section{METODE}

Jenis penelitian yang dilakukan dalam penelitian ini adalah jenis penelitian deskriptif dengan data kualitatif. Data yang diperoleh akan dianalisis dan diinterpretasikan sesuai dengan tujuan dan pernyataan penelitian yang telah ditemukan. Penelitian deskriptif merupakan data yang terkumpul beberntuk katakata atau gambar sehingga tidak menekankan pada angka. Data yang terkumpul setelah dianalisis selanjutnya dideskripsikan sehingga mudah dipahami oleh orang lain. Data yang diperoleh akan dianalisis dan diinterprestasikan sesuai dengan tujuan dan pernyataan penelitian. Dalam menentukan pengambilan informan menggunakan teknik purposive sampling yaitu penentuan sampel dengan pertimbangan tertentu. Informan penelitian terdiri dari 3 orang dari Dinas Pariwisata dan Kebudayaan Kabupaten Solok dan 2 orang pengelola di Villa Alahan Panjang Resort. Untuk mendapatkan data penelitian dilakukan dengan cara melakukan wawancara, observasi, dan dokumentasi. pertanyaan wawancara dilakukan menggunakan analisis SWOT (Strength, weakness, opportunity, dan treath). Teknik yang digunakan untuk menganalisis data yaitu analisis deskriptif kualitatif. 


\section{HASIL DAN PEMBAHASAN}

Hasil

Berdasarkan hasil penelitian dengan teknik wawancara, observasi dan dokumentasi peneliti mendapatkan hasil penelitian tentang promosi Villa Alahan Panjang Resort. Hasil analisis strategi promosi pada periklanan, berdasarkan hasil analisis SWOT yaitu sebagai berikut. Pertama, Strength. Hasil analisis pertama yaitu periklanan Villa Alahan Panjang Resort dengan iklan cetak memiliki potensi yang cukup bagus karena letak yang strategis dan memiliki banyak tempat untuk pemasangan maupun penyebaran dari iklan cetak berupa brosur dan spanduk. Kedua, periklanan dengan bentuk iklan cetak memiliki ketahan atau jangka waktu penggunaanya yang lebih lama. Ketiga, periklanan dalam bentuk iklan perusahaan Villa Alahan Panjang Resort memiliki potensi dengan promosi yang dipegang oleh Dinas Pariwisata sehingga iklan perusahaan yang dilakukan lebih luas. Keempat, selain Dinas Pariwisata promosi berupa iklan perusahaan juga dilakukan kerjasama dengan Dinas KOMINFO sehingga iklan perusahaan yang dilakukan lebih beragam dan lebih inovatif dengan mengikuti perkembangan zaman. Kelima yaitu dengan memanfaatkan ruang lingkup atau relasi yang dimiliki oleh Dinas Pariwisata dan KOMINFO maka periklanan yang dapat dilakukan oleh Villa Alahan Panjang Resort lebih berkembang lagi.

Hasil analisis weakness yaitu pertama, kelemahan dari periklanan berupa iklan cetak adalah dari segi anggaran, karena iklan cetak merupakan promosi dengan menampilkan fisik dari periklanan ini sendiri. Kedua, untuk iklan cetak berupa brosur kelemahannya dari segi penyebaranya, karena untuk membagikan iklan berupa brosur tentunya ketika pengunjung sudah datang berkunjung ke Villa Alahan Panjang Resort. Ketiga, periklanan yang berupa iklan perusahaan juga memiliki kelemahan dari segi anggaran karena anggarannya digabungkan dengan promosi destinasi wisata lainnya yang ada di Kabupaten Solok. Keempat, dengan dikelola sepenuhnya oleh dinas maka iklan perusahaan yang dilakukan tidak begitu leluasa kerena tergantung pada target pengembangan destinasi wisata yang ada di Kabupaten Solok secara menyeluruh.

Hasil analisis opportunity yaitu pertama, peluang dari periklanan Villa Alahan Panjang Resort berupa iklan cetak adalah dengan letak yang strategi sehingga untuk pemasangan iklan cetak dalam bentuk spanduk lebih luas seperti bisa dipasang di sekitar area Villa Alahan Panjang Resort maupun diluar area tersebut seperti di area Tugu Ayam Arosuka yang menjadi ikon Kabupaten Solok. Kedua, dengan adanya hubungan kerjasama antara Dinas Pariwisata dengan Dinas KOMINFO tentunya dalam pelaksanaan dari periklanan berupa iklan cetak maupun iklan perusahaan yang dilakukan berpeluang lebih luas dan lebih besar. Ketiga, dengan berada di bawah payung Dinas Pariwisata maka periklanan berupa iklan cetak maupun iklan perusahaan dapat ditingkatkan dengan memanfaatkan Duta Pariwisata Kabupaten Solok untuk melakukan dan menyebarkan promosi Villa Alahan Panjang Resort. Keempat, peluang lainnya adalah berdasarkan karakteristik dari pengunjung karena tidak semua pengunjung yang bisa menggunakan internet dan media sosial. Hasil analisis threats yaitu pertama, ancaman dari periklanan berupa iklan cetak adalah dengan berbaginya anggaran promosi Villa Alahan Panjang Resort dengan destinasi Wisata lainnya di Kabupaten Solok. Kedua, dari segi pesaing tentu juga memberi ancaman untuk periklanan baik berupa iklan cetak maupun iklan perusahaan karena mereka dikelola oleh pribadi maka akan lebih leluasa dalam melakukan kegiatan promosi. Ketiga, ancaman dari iklan cetak pada saat ini adalah promosi yang dilakukan melalui media sosial karena media sosial memiliki jangkauan lebih luas dari iklan cetak.

Hasil analisis strategi promosi penjualan, berdasarkan hasil analisis SWOT yaitu sebagai berikut. Hasil analisis strength, pertama promosi penjualan berupa pemberian Coupons merupakan bentuk promosi yang terbilang baru di Villa Alahan Panjang Resort, karena selama ini Villa Alahan Panjang Resort belum pernah menerapkan sistem pemberian Coupons kepada pengunjung. Kedua, dengan adanya pemberian Coupons maka akan meningkatkan daya tarik pengunjung. Ketiga, discount merupakan pemberian potongan harga dari harga sebenarnya, dengan ini maka Villa Alahan Panjang Resort dapat menarik perhatian pengunjung untuk menginap. Keempat, kekuatan dari promosi penjualan dengan adanya sistem cashback juga memberikan pengaruh bagi pengunjung, karena dengan sistem cashback ini pengunjung akan mendapatkan pengembalian dalam bentuk cash sesuai dengan syarat dan ketentuan yang berlaku. Kelima, sebelumnya promosi penjualan berupa Coupons, discount, dan cashback belum pernah dilakukan sama sekali. Hasil analisis weakness yaitu pertama, tidak adanya anggaran khusus untuk promosi Villa Alahan Panjang Resort untuk melakukan promosi penjualan berupa pemberian Coupons, discount, maupun cashback. Kedua, target yang diberikan oleh pemerintah sehingga untuk memberikan Coupons, discount, maupun cashback akan sedikit sulit karena juga tidak adanya anggaran khusus untuk Villa Alahan Panjang dalam melakukan promosi. Ketiga, sulitnya untuk menentukan syarat dan ketentuan dan seberapa besar pemebrian discount dan cashback karena semuanya diatur oleh pemerintah. Keempat, sulitnya menentukan kategori Coupons, cashback, maupun discount karena promosi penjualan ini belum pernah dilakukan. 
Hasil analisis opportunity yaitu belum pernah dilakukan promosi berupa promosi penjualan dengan pemberian Coupons, discounts, dan cashback maka akan berpeluang menarik perhatian pengunjung. Kedua, sistem promosi berupa Coupons, discounts, maupun cashback juga sudah familiar di kalangan pengunjung karena sudah banyak dipakai oleh banyak perusahaan yang bergerak dibidang produk maupun jasa. Ketiga, promosi berupa pemberian Coupons, discounts, dan cashback juga lebih menarik perhatian dan minat dari pengunjung. Hasil analisis threats yaitu pesaing yang berada disekitar Villa Alahan Panjang Resort. Kedua, destinasi wisata baru di Kabupaten Solok. Ketiga, kesulitan dalam mencapai target yang ditetapkan oleh pemerintah. Keempat, anggaran yang disediakan tidak hanya fokus ke promosi Villa Alahan Panjang Resort saja, karena belum pernah melakukan promosi penjualan berupa Coupons, discounts, maupun cashback.

Berdasarkan dari tabel analisis strategi SWOT diatas dapat dirangkum untuk melakukan promosi Villa Alahan Panjang Resort maka perlu diperhatikan faktor internal yang menjadi kekuatan dan kelemahan promosi dengan indikator periklanan dan promosi penjualan, serta faktor eksternal yang menjadi peluang dan ancaman promosi dengan indikator periklanan dan promosi penjualan Villa Alahan Panjang Resort.

Formulasi SWOT Periklanan yaitu dari segi Strengths (S) yaitu pertama, periklanan Villa Alahan Panjang Resort dengan iklan cetak memiliki potensi yang cukup bagus karena letak yang strategis dan memiliki banyak tempat untuk pemasangan maupun penyebaran dari iklan cetak berupa brosur dan spanduk. Weaknesses (W), Kelemahan dari periklanan berupa iklan cetak adalah dari segi anggaran, karena iklan cetak merupakan promosi dengan menampilkan fisik dari periklanan ini sendiri. Kedua, dari segi Strengths (S) yaitu periklanan dengan bentuk iklan cetak memiliki ketahan atau jangka waktu penggunaanya yang lebih lama. Weaknesses $(\mathrm{W})$, untuk iklan cetak berupa brosur kelemahannya dari segi penyebaranya, karena untuk membagikan iklan berupa brosur tentunya ketika pengunjung sudah datang berkunjung ke Villa Alahan Panjang Resort. Ketiga, dari segi Strengths (S) yaitu periklanan dalam bentuk iklan perusahaan Villa Alahan Panjang Resort memiliki potensi dengan promosi yang dipegang oleh Dinas Pariwisata sehingga iklan perusahaan yang dilakukan lebih luas. Weaknesses (W), periklanan yang berupa iklan perusahaan juga memiliki kelemahan dari segi anggaran karena anggarannya digabungkan dengan promosi destinasi wisata lainnya yang ada di Kabupaten Solok. Keempat, dari segi Strengths (S) yaitu selain Dinas Pariwisata promosi berupa iklan perusahaan juga dilakukan kerjasama dengan Dinas KOMINFO sehingga iklan perusahaan yang dilakukan lebih beragam dan lebih inovatif dengan mengikuti perkembangan zaman. Weaknesses (W), dengan dikelola sepenuhnya oleh dinas maka iklan perusahaan yang dilakukan tidak begitu leluasa kerena tergantung pada target pengembangan destinasi wisata yang ada di Kabupaten Solok secara menyeluruh. Kelima, dari segi Strengths (S) yaitu dengan memanfaatkan ruang lingkup atau relasi yang dimiliki oleh Dinas Pariwisata dan KOMINFO maka periklanan yang dapat dilakukan oleh Villa Alahan Panjang Resort lebih berkembang lagi.

Dari segi Opportunities (O) yaitu pertama, peluang dari periklanan Villa Alahan Panjang Resort berupa iklan cetak adalah dengan letak yang strategi sehingga untuk pemasangan iklan cetak dalam bentuk spanduk lebih luas seperti bisa dipasang di sekitar area Villa Alahan Panjang Resort maupun diluar area tersebut seperti di area Tugu Ayam Arosuka yang menjadi ikon Kabupaten Solok. Kedua, dengan adanya hubungan kerjasama antara Dinas Pariwisata dengan Dinas KOMINFO tentunya dalam pelaksanaan dari periklanan berupa iklan cetak maupun iklan perusahaan yang dilakukan berpeluang lebih luas dan lebih besar. Ketiga, dengan berada di bawah payung Dinas Pariwisata maka periklanan berupa iklan cetak maupun iklan perusahaan dapat ditingkatkan dengan memanfaatkan Duta Pariwisata Kabupaten Solok untuk melakukan dan menyebarkan promosi Villa Alahan Panjang Resort. Keempat, peluang lainnya adalah berdasarkan karakteristik dari pengunjung karena tidak semua pengunjung yang bisa menggunakan internet dan media sosial.

Dari Strategi SO yaitu pertama, memanfaatkan periklanan berupa iklan cetak seperti brosur dan spanduk karena periklan seperti itu memiliki ketahanan yang lama dan Villa Alahan Panjang Resort yang luas dapat digunakan sebagai tempat penyebaran brosur maupun spanduk. Kedua, membuat periklanan berupa iklan cetak semenraik mungkin dan kekinian karena Villa Alahan Panjang Resort dikelola oleh Dinas Pariwisata dan bekerja sama dengan Dinas KOMINFO Kabupaten Solok. Ketiga, membuat video Promosi Villa Alahan Panjang Resort karena dapat disiarkan di Tugu Ayam yang memiliki fasilitas untuk penayangan video promosi tersebut. Keempat, dengan adanya periklan berupa brosur dan spanduk yang dipasang di bebrapa titik yang potensial dapat menarik minat pengunjung ditambah tidak semua pengunjung yang melek teknologi. Dari strategi WO yaitu pertama, mencari investor yang mampu mengeluarkan dana yang cukup untuk pengelolaan Villa Alahan Panjang Resort untuk menambah anggaran pengelolaan termasuk promosi. Kedua, untuk penyebaran spanduk dan brosur dapat diperluas dengan memanfaatkan ruang lingkup Dinas Pariwisata dan memaksimalkan peranan Duta Wisata untuk melakukan promosi baik berupa iklan cetak maupun melalui iklan di media sosial. Ketiga, untuk 
pengelolaan utama dilakukan oleh pihak ketiga atau investor sehingga untuk kegiatan promosi bisa dilakukan lebih luas dan leluasa. Keempat, mencari sponsorhip sebanyak mungkin karena dapat memperluas lagi jangkauan promosi berupa iklan cetak dan iklan perusahaan Villa Alahan Panjang Resort dan juga membantu masalah anggaran.

Formulasi SWOT periklanan berdasarkan hasil analisis Threats yaitu pertama, ancaman dari periklanan berupa iklan cetak adalah dengan berbaginya anggaran promosi Villa Alahan Panjang Resort dengan destinasi Wisata lainnya di Kabupaten Solok. Kedua, dari segi pesaing tentu juga memberi ancaman untuk periklanan baik berupa iklan cetak maupun iklan perusahaan karena mereka dikelola oleh pribadi maka akan lebih leluasa dalam melakukan kegiatan promosi. Ketiga, ancaman dari iklan cetak pada saat ini adalah promosi yang dilakukan melalui media sosial karena media sosial memiliki jangkauan lebih luas dari iklan cetak. Formulasi strategi ST yaitu pertama, menetapkan anggaran khusus untuk Villa Alahan Pnajang Resort dari pemerintah untuk kegiatan promosi berupa iklan cetak karena iklan cetak ini merupakan salah satu promosi jangka panjang dengan penggunaanya dalam kurun waktu lama. Kedua, dengan adanya kerjasama dengan Dinas KOMINFO untuk periklanan dapat dilakukan dengan beberapa media yang dipegang oleh Dinas KOMINFO sehingga bisa bersaing dengan perusahaan serupa. Ketiga, dengan letak yang strategis dapat disebarkan iklan cetak berupa spanduk dan brosur di berbagai titik potensial sehingga tidak tertutupi oleh periklanan melalui media sosial. Keempat, dengan pengelolaan yang dipegang oleh Dinas Pariwisata maka dapat dipasang periklanan Villa Alahan Panjang Resort di destinasi wisata yang ada di Kabupaten Solok. Formulasi strategi WT yaitu pertama, menemukan investor dan sponsor yang siap mengeluarkan anggaran besar untuk pengembangan, operasional dan promosi Villa Alahan Panjang Resort sehingga tidak bergantung pada anggaran dari pemerintah. Kedua, memaksimalkan sumber daya manusia yang dimiliki oleh Dinas Pariwisat seperti Duta Wisata untuk melakukan promosi. Ketiga, membuat spanduk dan brosur yang mengikuti perkembangan zaman, dan memanfaatkan media sosial dengan maksimal sebagai media promosi.

Formulasi SWOT Promos Penjualan yaitu sebagai berikut. Dari segi Strengths yaitu pertama, promosi penjualan berupa pemberian Coupons merupakan bentuk promosi yang terbilang baru di Villa Alahan Panjang Resort, karena selama ini Villa Alahan Panjang Resort belum pernah menerapkan sistem pemberian Coupons kepada pengunjung. Kedua, dengan adanya pemberian Coupons maka akan meningkatkan daya tarik pengunjung. Ketiga, discount merupakan pemberian potongan harga dari harga sebenarnya, dengan ini maka Villa Alahan Panjang Resort dapat menarik perhatian pengunjung untuk menginap. Keempat, kekuatan dari promosi penjualan dengan adanya sistem cashback juga memberikan pengaruh bagi pengunjung, karena dengan sistem cashback ini pengunjung akan mendapatkan pengembalian dalam bentuk cash sesuai dengan syarat dan ketentuan yang berlaku. Dari Segi Weaknesses yaitu pertama, tidak adanya anggaran khusus untuk promosi Villa Alahan Panjang Resort untuk melakukan promosi penjualan berupa pemberian Coupons, discount, maupun cashback. Kedua, target yang diberikan oleh pemerintah sehingga untuk memberikan Coupons, discount, maupun cashback akan sedikit sulit karena juga tidak adanya anggaran khusus untuk Villa Alahan Panjang dalam melakukan promosi. Ketiga, sulitnya untuk menentukan syarat dan ketentuan dan seberapa besar pemebrian discount dan cashback karena semuanya diatur oleh pemerintah. Keempat, sulitnya menentukan kategori Coupons, cashback, maupun discount karena promosi penjualan ini belum pernah dilakukan.

Dari Opportunities (0) yaitu pertama, belum pernah dilakukan promosi berupa promosi penjualan dengan pemberian Coupons, discounts, dan cashback maka akan berpeluang menarik perhatian pengunjung. Kedua, sistem promosi berupa Coupons, discounts, maupun cashback juga sudah familiar di kalangan pengunjung karena sudah banyak dipakai oleh banyak perusahaan yang bergerak dibidang produk maupun jasa. Ketiga, promosi berupa pemberian Coupons, discounts, dan cashback juga lebih menarik perhatian dan minat dari pengunjung. Dari Strategi So yaitu pertama, memanfaatkan promosi penjualan berupa pemberian Coupons, discount, dan cashback untuk menarik minat pengunjung lebih besar lagi. Kedua, membuat Coupons berupa showing beberapa destinasi wisata yang ada di Kabupaten Solok seperti ke pabrik teh PTPN 6 Kayu Jao, kebun strawberry dan lainnya. Ketiga, memberikan discounts untuk menggunakan fasilitas Convention Center untuk melaksanakan event wedding dan meeting, Keempat, Menerapkan sistem cashback untuk event-event besar. Strategi WO yaitu pertama, menetapkan anggaran khusus untuk Villa Alahan Panjang Resort untuk melakukan promosi penjualan berupa adanya Coupons, discount, maupun cashback di Villa Alahan Panjang Resort. Kedua, melakukan kerjasama dengan Travel Agent untuk mempromosikan Villa Alahan Panjang Resort dengan adanya Coupons, discount, dan cashback sehingga dapat menjangkau pasar yang lebih luas.

Formulasi SWOT Promosi Penjualan (Sales Promotion) dari segi Treats (T) yaitu pertama, pesaing yang berada disekitar Villa Alahan Panjang Resort. Kedua, destinasi wisata baru di Kabupaten Solok. Ketiga, kesulitan dalam mencapai target yang ditetapkan oleh pemerintah. Keempat, anggaran yang disediakan tidak hanya fokus ke promosi Villa Alahan Panjang Resort saja, karena belum pernah 
melakukan promosi penjualan berupa Coupons, discounts, maupun cashback. Strategi ST yaitu pertama, memberikan Coupons, discount, dan casback yang lebih menarik untuk dapat bersaing dengan kompetitor. Kedua, melakukan kerjasama dengan destinasi wisata yang ada di Kabupaten Solok untuk menerapkan sistem Coupons. Ketiga, menetapkan syarat dan ketentuan dari sistem Coupons, discount dan cashback sehingga tetap dapat mencapai target yang telah ditetapkan oleh pemerintah. Strategi WT yaitu pertama, mencari tahu promosi penjualan berupa Coupons, discount, dan cash back yang dilakukan oleh pesaing dari Villa Alahan Panjang Resort. Kedua, mencari sponsor untuk meminimalisir anggaran dari pemerintah sehingga dapat melakukan promosi penjualan berupa pemberian Coupons, discount, dan cashback dengan tetap memenuhi target yang ditetapkan pemerintah.

\section{Pembahasan}

Memanfaatkan periklanan dalam memasarkan produk sangatlah penting dalam memasarkan sebuah produk (Karray et al., 2022; Wiktor \& Sanak-Kosmowska, 2021; Yang \& Zhai, 2022). Periklanan (Adveristing) yang dapat diterapkan untuk promosi Villa Alahan Panjang Resort berupa iklan cetak dan iklan perusahaan dalam upaya menarik minat pengunjung adalah: Pertama, memanfaatkan periklanan berupa iklan cetak seperti brosur dan spanduk karena periklan seperti itu memiliki ketahanan yang lama dan Villa Alahan Panjang Resort yang luas dapat digunakan sebagai tempat penyebaran brosur maupun spanduk. Brosur dan spanduk dapat digunakan sebagai media promosi (Lengkong et al., 2018; Susanty \& Adiati, 2014). Kedua, Membuat periklanan berupa iklan cetak semenraik mungkin dan kekinian karena Villa Alahan Panjang Resort dikelola oleh Dinas Pariwisata dan bekerja sama dengan Dinas KOMINFO Kabupaten Solok. Ketiga, Membuat video Promosi Villa Alahan Panjang Resort karena dapat disiarkan di Tugu Ayam yang memiliki fasilitas untuk penayangan video promosi tersebut. Video promosi dapat menarik minat (Indiyati et al., 2020; Yudani, 2018). Keempat, dengan adanya periklan berupa brosur dan spanduk yang dipasang di bebrapa titik yang potensial dapat menarik minat pengunjung ditambah tidak semua pengunjung yang melek teknologi. Kelima, mencari investor yang mampu mengeluarkan dana yang cukup untuk pengelolaan Villa Alahan Panjang Resort untuk menambah anggaran pengelolaan termasuk promosi. Keenam, Untuk penyebaran spanduk dan brosur dapat diperluas dengan memanfaatkan ruang lingkup Dinas Pariwisata dan memaksimalkan peranan Duta Wisata untuk melakukan promosi baik berupa iklan cetak maupun melalui iklan di media sosial. Ketujuh, Mencari sponsorhip sebanyak mungkin karena dapat memperluas lagi jangkauan promosi berupa iklan cetak dan iklan perusahaan Villa Alahan Panjang Resort dan juga membantu masalah anggaran. Kedelapan, dengan adanya kerjasama dengan Dinas KOMINFO untuk periklanan dapat dilakukan dengan beberapa media yang dipegang oleh Dinas KOMINFO sehingga bisa bersaing dengan perusahaan serupa.

Promosi penjualan yang dapat dilakukan untuk mempromosikan Villa Alahan Panjang resort adalah sebagai berikut: Pertama, Memanfaatkan promosi penjualan berupa pemberian Coupons, discount, dan cashback untuk menarik minat pengunjung lebih besar lagi. Pemberian diskon dapat menarik minat konsumen (Chen et al., 2022; Dogerlioglu-Demir et al., 2022; Li et al., 2020). Kedua, Membuat Coupons berupa showing beberapa destinasi wisata yang ada di Kabupaten Solok seperti ke pabrik teh PTPN 6 Kayu Jao, kebun strawberry dan lainnya. Ketiga, Memberikan discounts untuk menggunakan fasilitas Convention Center untuk melaksanakan event,wedding dan meeting. Keempat, Menerapkan sistem cashback untuk event-event besar. Kelima, Menetapkan anggaran khusus untuk Villa Alahan Panjang Resort untuk melakukan promosi penjualan berupa adanya Coupons, discount, maupun cashback di Villa Alahan Panjang Resort. Keenam, Melakukan kerjasama dengan Travel Agent untuk mempromosikan Villa Alahan Panjang Resort dengan adanya Coupons, discount, dan cashback sehingga dapat menjangkau pasar yang lebih luas. Ketujuh, memberikan Coupons, discount, dan casback yang lebih menarik untuk dapat bersaing dengan kompetitor. Kedelapan, melakukan kerjasama dengan destinasi wisata yang ada di Kabupaten Solok untuk menerapkan sistem Coupons. Kesembilan, Menetapkan syarat dan ketentuan dari sistem Coupons, discount dan cashback sehingga tetap dapat mencapai target yang telah ditetapkan oleh pemerintah. Kesepuluh, Mencari tahu promosi penjualan berupa Coupons, discount, dan cash back yang dilakukan oleh pesaing dari Villa Alahan Panjang Resort. Temuan penelitian sebelumnya juga menyatakan bahwa melakukan promosi penjualan sangat penting untuk dilakukan untuk meningkatkan pendapatan (Bandyopadhyay et al., 2021; Jee, 2021; Sinha \& Verma, 2020). Mencari sponsor untuk meminimalisir anggaran dari pemerintah sehingga dapat melakukan promosi penjualan berupa pemberian Coupons, discount, dan cashback dengan tetap memenuhi target yang ditetapkan pemerintah.

\section{SIMPULAN}

Faktor internal (kekuatan dan Kelemahan) dari strategi promosi Villa Alahan Panjang Resort berdasarkan periklanan dan promosi penjualan adalah strategi promosi yang bisa dilakukan di Villa 
Alahan Panjang Resort Kabupaten Solok melihat sistem pengelolaanya adalah dengan mamaksimalkan promosi berupa periklanan baik dalam bentuk iklan cetak maupun iklan perusahaan berupa pemasangan spanduk di beberapa area potensial. Penggunaan media sosial sebagai media promosi yang lebih luas. Dan untuk promosi penjualan Villa Alahan Panjang Resort dengan mengadakan promosi dengan menggunakan sistem Coupons, discount, dan cashback. Untuk faktor eksternal strategi promosi Villa Alahan Panjang Resort dengan mengupayakan untuk mencari investor agar mencukupi anggaran yang diperlukan dalam operasional dan promosi.

\section{DAFTAR PUSTAKA}

Ali, N. A. M., Gafar, M. H. A., \& Akbar, J. (2013). Enhancing Promotional Strategies within Automotive Companies in Malaysia. Procedia Economics and Finance, 7. https://doi.org/10.1016/S22125671(13)00230-X.

Andrinata, Sumarmi, \& I Komang Astina. (2016). Pengembangan Modul Geografi Pariwisata Berbasis Paket Wisata Pulau Lombok Sebagai Upaya Memupuk Rasa Cinta Tanah Air Pada Mahasiswa. Jurnal Pendidikan: Teori, Penelitian, Dan Pengembangan, 1(10), 1999-2003. https: //doi.org/10.17977/jp.v1i10.7339.

Atiko, G., Sudrajat, R. H., \& Nasionalita, K. (2016). Analisis Strategi Promosi Pariwisata Melalui Media Sosial Oleh Kementerian Pariwisata RI (Studi Deskriptif Pada Akun Instagram @Indtravel). Jurnal Sosioteknologi, 15(3), 378-389. https://doi.org/10.5614/sostek.2016.15.3.6.

Avello Martínez, R., \& López Fernández, R. (2015). Digital literacy for teachers in Cuban Tourism and Hotel Management Schools. Some experiences on its development. RUSC. Universities and Knowledge Society Journal. https://doi.org/10.7238/rusc.v12i3.1994.

Bandyopadhyay, N., Sivakumaran, B., Patro, S., \& Kumar, R. S. (2021). Immediate or delayed! Whether various types of consumer sales promotions drive impulse buying?: An empirical investigation. Journal of Retailing and Consumer Services, 61. https://doi.org/10.1016/j.jretconser.2021.102532.

Chen, P., Chen, H., \& Zhao, R. (2022). Price promotions in vertically-related market: Instant discount vs. gift card. Omega: Jurnal Fisika Dan Pendidikan Fisika, 108. https://doi.org/10.1016/j.omega.2021.102588.

Cowan, K. (2020). Anything you can imagine is possible: How imagining can overcome visceral drive states elicited in promotional advertising. Journal of Business Research, 120. https://doi.org/10.1016/j.jbusres.2019.04.008.

Desmira, D., Aribowo, D., Ekawati, R., \& Wahyuni, A. P. (2021). Video Promosi Wisata “Cikal Adventure” Di Kecamatan Padarincang. Kaibon Abhiyana, 3(2). https://doi.org/10.30656/ka.v3i2.2940.

Dogerlioglu-Demir, K., Akpinar, E., Gurhan-Canli, Z., \& Koçaş, C. (2022). Are 1-endings the new 9-endings? An alternative for generating price discount perceptions. Journal of Retailing and Consumer Services, 66. https://doi.org/10.1016/j.jretconser.2022.102912.

English, L. M., Hsia, J., \& Malarcher, A. (2016). Tobacco advertising, promotion, and sponsorship (TAPS) exposure, anti-TAPS policies, and students' smoking behavior in Botswana and South Africa. Preventive Medicine, 91. https://doi.org/10.1016/j.ypmed.2016.01.014.

Fan, X., Li, J., Mao, Z. (Eddie), \& Lu, Z. (2021). Can ethical leadership inspire employee loyalty in hotels in China? -From the perspective of the social exchange theory. Journal of Hospitality and Tourism Management, 49. https://doi.org/10.1016/j.jhtm.2021.11.006.

Fransiska, Y., Andhika, F., Indra, M., \& Rengganis, R. (2012). Determining the Most Effective Promotion Strategy for Clothing Company in Bandung, Indonesia. Procedia Economics and Finance, 4. https://doi.org/10.1016/S2212-5671(12)00327-9.

Freixanet, J. (2016). Export promotion programs: Their impact on companies' internationalization performance and competitiveness. International Business Review, 21(6). https: //doi.org/10.1016/j.ibusrev.2011.12.003.

Hanaysha, J. . (2017). Impact of Social Media Marketing, Price Promotion, and Corporate Social Responsibility On Customer Satisfaction. Jindal Journal of Business Research, 6(15), 1-14. https://doi.org/10.1177/2278682117715359.

Handoko, B. (2017). Pengaruh Promosi, Harga Dan Kualitas Pelayanan Terhadap Kepuasan Konsumen Pada Titipan Kilat JNE Medan. Jurnal Ilmiah Manajemen Dan Bisnis, 18(1), 61-72. https://doi.org/10.30596\%2Fjimb.v18i1.1098.

Hao, F., Xiao, Q., \& Chon, K. S. (2020). COVID-19 and China's Hotel Industry: Impacts, a Disaster Management Framework, and Post-Pandemic Agenda. International Journal of Hospitality Management, 90. https://doi.org/10.1016/j.ijhm.2020.102636.

Indiyati, D., Khusnia, H. N., \& Chotijah, S. (2020). Optimalisasi Gerakan Sadar Wisata melalui Produksi 
Video Promosi Desa Wisata. Jurnal Pengabdian Kepada Masyarakat, 5(2). https://doi.org/10.30653/002.202052.510.

Jee, T. W. (2021). The perception of discount sales promotions - A utilitarian and hedonic perspective. Journal of Retailing and Consumer Services, 63. https://doi.org/10.1016/j.jretconser.2021.102745.

Karray, S., Martín-Herrán, G., \& Sigué, S. P. (2022). Managing advertising investments in marketing channels. Journal of Retailing and Consumer Services, 65. https://doi.org/10.1016/j.jretconser.2021.102852.

Kotler, Philip \& Keller, K. L. (2016). Marketing Management (15th ed.).

Kotler, P., \& Amstrong, G. (2012). Manajemen Pemasaran (Prinsip-prinsip manajemen pemasaran) (Erlangga (ed.); 12th ed.).

Kurniasanti, S. A., Sumarwan, U., \& Kurniawan, B. P. Y. (2015). Analisis dan Model Strategi Peningkatan Daya Saing Produk Edamame Beku. Jurnal Manajemen \& Agribisnis, 11(3). https://doi.org/10.17358/jma.11.3.154-163.

Lang, L. D., Lim, W. M., \& Guzmán, F. (2022). How does promotion mix affect brand equity? Insights from a mixed-methods study of low involvement products. Journal of Business Research, 141. https://doi.org/10.1016/j.jbusres.2021.12.028.

Lengkong, O., Wahyudi, A. K., \& Najoan, A. (2018). Media Informasi Brosur Fakultas Ilmu Komputer Universitas Klabat menggunakan Augmented Reality Dalam Bentuk Video. Jurnal Teknologi Informasi, 17(2). https://doi.org/10.33633/tc.v17i2.1621.

Li, C., Chu, M., Zhou, C., \& Zhao, L. (2020). Two-period discount pricing strategies for an e-commerce platform with strategic consumers. Computers \& Industrial Engineering, 147. https://doi.org/10.1016/j.cie.2020.106640.

Lim, S. (Edward), \& Chihyung. (2022). A percentage-off discount versus free surcharge: The impact of promotion type on hotel consumers' responses. Tourism Management, 91. https://doi.org/10.1016/j.tourman.2022.104504

Malaquias, R. F., Junior, D. M. B., Malaquias, F. F. de O., \& Albertin, A. L. (2019). Climate protection or corporate promotion? Energy companies, development, and sustainability reports in Latin America. Energy Research \& Social Science, 54. https://doi.org/10.1016/j.erss.2019.04.001.

Nugroho, M. S., Islam, U., Mataram, N., Program, D., Pariwisata, S., Baloq, L., Baloq, P. L., \& Pariwisata, P. (2019). Sikap Masyarakat Terhadap Pengembangan Pantai Loang Baloq Sebagai Daya Tarik Wisata di Kota Mataram. Journal of Enterprise and Development, 1(2), 51-61. https://doi.org/10.20414/jed.v1i02.979.

Paramita, I. B. G., \& Putra, I. G. G. P. A. (2020). New Normal Bagi Pariwisata Bali Di Masa Pandemi Covid 19. Jurnal Ilmiah Pariwisata Agama Dan Budaya, 5(2). https://doi.org/10.25078/pba.v5i2.1723.

Peñate-Valentín, M. C., Sánchez-Carreira, M. del C., \& Pereira, Á. (2021). The promotion of innovative service business models through public procurement. An analysis of Energy Service Companies in Spain. Sustainable Production and Consumption, 27. https://doi.org/10.1016/j.spc.2021.04.028.

Perles-Ribes, J. F., Ramón-Rodríguez, A. B., Sevilla-Jiménez, M., \& Moreno-Izquierdo, L. (2016). Unemployment effects of economic crises on hotel and residential tourism destinations: The case of Spain. Tourism Management, 54. https://doi.org/10.1016/j.tourman.2015.12.002.

Pratiwi, D. P. E., Ayomi, P. N., \& Candra, K. D. P. (2017). Balinese Arts And Culture As Tourism Commodity In Bali Tourism Promotion Videos. MUDRA: JURNAL SENI BUDAYA, 32(3). https://doi.org/10.31091/mudra.v32i3.178.

Ramanathan, U., \& Muyldermans, L. (2010). Identifying demand factors for promotional planning and forecasting: A case of a soft drink company in the UK. International Journal of Production Economics, 128(2). https://doi.org/10.1016/j.ijpe.2010.07.007.

Rosidi, A. R., Mustaniroh, S. A., \& Deoranto, P. (2017). Perencanaan Strategi Pengembangan Agroindustri Kopra (Studi Kasus Di Kabupaten Halmahera Timur). Jurnal Teknilogi Pertanian, 18(3). https://doi.org/10.21776/ub.jtp.2017.018.03.21.

Sinha, S. K., \& Verma, P. (2020). Impact of sales Promotion's benefits on perceived value: Does product category moderate the results? Journal of Retailing and Consumer Services, 52. https://doi.org/10.1016/j.jretconser.2019.101887.

Sun, S., Lee, P. C., Law, R., \& Hyun, S. S. (2020). An investigation of the moderating effects of current job position level and hotel work experience between technology readiness and technology acceptance. International Journal of Hospitality Management, 90. https://doi.org/10.1016/j.ijhm.2020.102633.

Susanty, A., \& Adiati, W. (2014). Pemilihan Strategi Pemasaran Di Kampoeng Kopi Banaran Menggunakan Pendekatan Metode Analytical Network Process (Anp) Dan Technique For Order Preference By Similarity To An Ideal Solution (Topsis). Undip: Jurnal Teknik Industri, 9(3). 
https://doi.org/10.12777/jati.9.3.163-172.

Wikrama, M., Suarnajaya, I. W., \& Budasi, I. G. (2017). An Analysis of Jargon Used by Receptionists In Front Office at Lovina Beach Hotel. Jurnal Pendidikan Bahasa Inggris Undiksha, 5(2). https: //doi.org/10.23887/jpbi.v5i2.12235.

Wiktor, J. W., \& Sanak-Kosmowska, K. (2021). The Competitive Function of Online Advertising. An Empirical Evaluation of Companies' Communication Strategies in a Digital World. Procedia Computer Science, 192. https://doi.org/10.1016/j.procs.2021.09.191.

Yang, Y., \& Zhai, P. (2022). Click-through rate prediction in online advertising: A literature review. Information Processing \& Management, 59(2). https://doi.org/10.1016/j.ipm.2021.102853.

Yudani, H. D. (2018). Perancangan Video Iklan Destination Branding Kabupaten Kediri. Nirmana, 17(1). https://doi.org/10.9744/nirmana.17.1.22-29. 